Article

\title{
Generation Z and Organizational Listening on Social Media
}

\author{
Hanna Reinikainen *, Jaana T. Kari and Vilma Luoma-aho \\ Jyväskylä University School of Business and Economics, 40014 Jyväskylä, Finland; \\ E-Mails: hanna.m.reinikainen@jyu.fi (H.R.), jaana.t.kari@jyu.fi (J.T.K.), vilma.luoma-aho@jyu.fi (V.L.-a.) \\ * Corresponding author
}

Submitted: 9 January 2020 | Accepted: 21 April 2020 | Published: 19 May 2020

\begin{abstract}
Young people are avid users of social media and have appeared as a powerful force for social change, as shown by the ranks of those who have joined Greta Thunberg in the global climate movement. In addition to challenging political institutions and governments, young people today are also holding the corporate world accountable. To respond to young people's expectations, brands, and organizations have turned to social media to interact and build relationships with them. However, critics have lamented that these attempts often fail and that young people's trust in institutions, brands, and organizations continues to decline. This article asks how young people perceive organizational listening on social media and whether their perceptions are related to their trust in the information shared by brands and other organizations on social media. Data for the study were gathered through an online survey in Finland and the UK. The respondents $(\mathrm{N}=1,534)$, aged 15-24, represent the age cohort known as Generation Z. The results show that organizational listening is connected to higher levels of perceived benefits from social media as well as higher levels of trust in the information that brands, public authorities, and non-governmental organizations share on social media. The results highlight the role of competent listening on social media, bolstering the previous literature connecting both organizational listening and trust with higher levels of participation and engagement online.
\end{abstract}

\section{Keywords}

brands; organizational listening; generation Z; social media; trust

\section{Issue}

This article is part of the issue "Youth Digital Participation: Opportunities, Challenges, Contexts, and What's at Stake" edited by Neta Kligler-Vilenchik (Hebrew University of Jerusalem, Israel) and Ioana Literat (Teachers College, Columbia University, USA).

(C) 2020 by the authors; licensee Cogitatio (Lisbon, Portugal). This article is licensed under a Creative Commons Attribution 4.0 International License (CC BY).

\section{Introduction}

Young people have emerged as a powerful force for change, both online and offline. In December 2019, Time magazine named the 16-year-old Greta Thunberg as Person of the Year for inspiring a global movement demanding more forceful action against climate change (Alter, Haynes, \& Worland, 2019). High school students have also championed the end of gun violence through the \#NeverAgain movement (Alter, 2018) and have actively participated in the protests against China's ruling party in Hong Kong (Khan, Wang, \& Yoon, 2019).

However, although young people are arguably more politically active than before (Kim, Russo, \& Amnå, 2017), their calls for change are not limited to political issues and governments. Young people today are also challenging the corporate world and expect brands to have a higher purpose beyond the pursuit of economic gains and even take the lead on social change where possible (Edelman, 2018; Minár, 2016). Many brands have answered these calls and have even adopted an approach called "corporate social advocacy" (Dodd \& Supa, 2014) or "corporate activism" (Olkkonen \& Jääskeläinen, 2019). Examples of such behavior include Nike's collaboration with Colin Kaepernick, the NFL player known for his stand against police violence and racial injustice in America ("Nike's 'dream crazy' advert," 2019), and Gillette's \#MeToo-inspired campaign calling for a new 
kind of masculinity (Topping, Lyons, \& Weaver, 2019). Both campaigns have generated heightened emotionsboth positive and negative-on social media.

Olkkonen and Jääskeläinen (2019) have called this kind of corporate activism "mobilizing talk," meaning that brands that raise societal issues in their communication invite discussion and action from consumers and stakeholders, all the while accepting that this might generate critique and even lead to consumers boycotting them. This shows how the lines between branding, politics, and emotion are becoming increasingly blurred and how brands are seeking to build emotional relationships with consumers online (Mukherjee \& Banet-Weiser, 2012, p. 19).

While it might seem that young people's activism in driving social change are coalescing with the more societally tuned pursuits of brands, it appears that brands and organizations often fail in achieving true interaction and relationship-building with young people in the online environment (Avidar, Ariel, Malka, \& Levy, 2013). In fact, studies have reported on diminishing trust among young people in relation to political institutions, media, and the corporate world (Deloitte, 2019; Edelman, 2018, 2020).

A relatively widely shared understanding among communication scholars is that an ideal way of closing this gap would be through fostering dialogue (Hung-Baesecke \& Chen, 2020; Kent \& Taylor, 1998; Lane, 2018; Sommerfeldt \& Kent, 2015). True dialogue values sharing and mutual understanding (Taylor \& Kent, 2014, p. 388) and is based on seeing communication partners as equals, not simply as recipients of persuasive messages (Sommerfeldt \& Yang, 2018). However, it seems that instead of real dialogue, brands and organizations often engage in mere two-way communication (Lane, 2018; Russmann \& Lane, 2020), or even one-way communication, which allows them to push their messages on social media with "little regard for interaction and dialogue, and no need for empathic and active listening" (Maben \& Gearhart, 2018, p. 103).

It has, therefore, been established that an important aspect of dialogue is often missing: organizational listening (Maben \& Gearhart, 2018; Macnamara, 2016, 2018b). This perspective highlights that dialogue is more than interactants taking turns recalling their respective lines; rather, it is an act of connecting a "chain of utterances" through listening to one another (Macnamara, 2016). Listening can be seen as a prerequisite to dialogue, understood as enabling a sense of community among those who feel engaged and empowered (Rissanen \& Luoma-aho, 2016; Smith \& Taylor, 2017).

Employing an online survey, this article explores how young people perceive organizational listening on social media and whether organizational listening is related to trust in the information that brands and organizations share on social media. The young people of interest to this study represent Generation Z, people born circa 1995-2010 (Priporas, Stylos, \& Fotiadis, 2017; Turner,
2015), the age cohort following Millennials. More information about this age cohort is needed, as they have already become a strategic target group for many brands and organizations, despite their young age (Len-Ríos, Hughes, McKee, \& Young, 2016).

The organizational listening approach offers insights into youth participation, as organizational listening has been connected to increased levels of participation in civil society (Macnamara, 2018a, 2018b). Society itself could be understood to exist on the basis of dialogue between different societal actors (Taylor, 2011), such as organizations and brands, different political and public sector organizations, and non-governmental organizations (NGOs). Ideally, dialogue between societal actors does not only empower those who are engaged; its benefits also spill over to society as a whole (Putnam, 2002; Rothstein \& Stolle, 2008). Therefore, this study takes a look at whether organizational listening by brands on social media could be connected with trust in the information shared not just by brands but also by other societal actors, such as public authorities and NGOs.

\section{Literature Review}

\subsection{Generation Z}

Generation Z, also known as Net Gen or digital natives, are the age cohort born after the commercial success of the Internet, circa 1995-2010 (Priporas et al., 2017; Turner, 2015). As the generation that has, from the onset, been continuously exposed to the Internet, social networks, and mobile systems (Francis \& Hoefel, 2018), many representatives of Generation Z have become accustomed to interacting in a world that is "connected at all times" (Turner, 2015, p. 104).

The imminent and instantaneous nature of the digitalized world has arguably made Generation Z more demanding than earlier generations, and studies have found that they expect interactivity (Southgate, 2017) and value easy and quick transactions and information provision online (Priporas et al., 2017). This tests their relationship with brands and organizations: When compared to Generations $X$ and $Y$, the representatives of Generation Z have been found to place more trust in user-generated information than on company-generated information (Francis \& Hoefel, 2018; Herrando, Jimenez-Martinez, \& Martin-De Hoyos, 2019).

Key among the societal experiences of Generation Z are the financial crisis of 2008, the growing income gap, the rise of the platform economy, and the increasing acceptance of the LGBTQ community (Francis \& Hoefel, 2018; Turner, 2015). Fear of climate change and a motivation to reverse it also profile many in the Generation Z cohort, which has led to, for example, school strikes for climate change (Barbiroglio, 2019; Ostrander, 2019).

While many of the above depictions about Generation $\mathrm{Z}$ might be accurate, it is important to remember that many of the studies related to this age co- 
hort are snapshots. Generational cohorts develop certain attitudes and beliefs based on shared life experiences (Meriac, Woehr, \& Banister, 2010), but it is difficult to tell at this point whether the features observed in this age cohort are something that they will grow out of or something that they will grow up with (Southgate, 2017).

\subsection{Organizational Listening on Social Media}

Social media has offered brands and organizations new opportunities not only to speak directly to consumers and stakeholders but also to listen to their needs, opinions, and concerns more carefully. The concept of organizational listening was introduced to communication studies specifically through the works of Macnamara (2016, 2018a, 2018b, 2019), who defined the phenomenon through "the seven canons of listening." These include the recognition and acknowledgement of others, paying attention to others, interpreting and understanding others, considering what others are saying, and responding appropriately (Macnamara, 2018a, pp. 119-120).

These "canons" come close to what Maben and Gearhart (2018) have defined as competent organizational listening: organizational behaviors such as pertinent responding, answering questions, elaborating on the topics being discussed, offering advice, opinions, and perspectives, and asking questions. Organizational listening differs from interpersonal listening, in that, although it is carried out by people working in an organization, it is delegated, mostly mediated, often asynchronous, and "scaled up," as the number of people that organizations need to listen to can feature in the hundreds of thousands or even millions (Macnamara, 2018b, p. 3).

Listening is considered vital for brands and organizations to achieve two-way communication and dialogue (Macnamara, 2016). Organizational listening brings many advantages to organizations themselves, such as strengthening relationships with consumers, improving customer satisfaction (Pina et al., 2019), and gaining a better understanding of how the organization is being discussed online (Crawford, 2009, pp. 531-532). Organizational listening can also benefit consumers and stakeholders by, for example, increasing their sense of community (Crawford, 2009). It is also expected to have other positive repercussions and societal benefits, such as equitable representation, increased participation in politics and civil society, and increased trust and social equity (Macnamara, 2018b). Through these effects, organizational listening might even improve collaboration in societies at large (Putnam, 2002, 2015).

Although people expect organizations to listen to them and give them quality answers (Lovari \& Parisi, 2015; Maben \& Gearhart, 2018), studies have shown that listening is not very well practiced in reality (Maben \& Gearhart, 2018; Macnamara, 2016, 2018a, 2018b, 2019; Willis, 2015). Willis (2015) has pointed out that organizations are primarily involved in monitoring or surveilling instead of actually listening. This suggests that organizations are inclined to use their resources for reputation management and monitoring (Vos, 2016) in order to avoid financial risk rather than for the purpose of truly competently listening to the sentiments of stakeholders and connecting with them in meaningful ways (Maben \& Gearhart, 2018). This may be harmful, as the potential societal benefits may be lost, such as a sense of community or a sense of empowerment. To tackle this, Macnamara $(2016,2018 a, 2018 b)$ has suggested that brands and organizations should seek to create a special "architecture of listening" to enable them to further ethical listening.

Previous research on organizational listening has mainly considered how organizations understand and approach listening (Burnside-Lawry, 2012; Dodd \& Collins, 2017; Maben \& Gearhart, 2018; Macnamara, 2016, 2018a, 2018b, 2019). To capture the views of consumers and stakeholders, researchers have mostly used content analysis (Ji, Li, North, \& Liu, 2017; Pina et al., 2019; Tirkkonen \& Luoma-aho, 2011), although surveys (Cheng, Jin, Hung-Baesecke, \& Chen, 2019; Lovari \& Parisi, 2015) have also been used.

According to Macnamara (2018b), further research is necessary, as organizational listening is undertheorized, and the potential benefits of improved organizational listening need further clarification. As organizational listening arguably ensures that both the organization's and stakeholders' interests are met (Burnside-Lawry, 2012), it is potentially beneficial not only to brands and organizations themselves but also to the people who engage with them through social media. Therefore, the first two hypotheses have been formulated on the basis of the previous literature:

$\mathrm{H} 1$ : Perceived organizational listening is positively associated with the perception that brands on social media benefit young people.

$\mathrm{H} 2$ : Perceived organizational listening is positively associated with the perception that brands on social media benefit brands.

\subsection{Trust and Organizational Listening}

According to Macnamara (2018b), more and more people have the experience of "being ignored" both by political institutions and the corporate world. Macnamara (2018b) has further connected this lack of listening by organizations to declining trust in public authorities, corporations, and NGOs, which has been reported, for example, through the annual Edelman Trust Barometer (Edelman, 2018, 2020). This can be regarded as potentially harmful, as people come in constant contact with government actors, corporations, and nongovernmental and non-profit organizations, all of which play a central role in people's lives (Macnamara, 2018b).

In order to contribute to our understanding about the phenomenon, Hung-Baesecke and Chen (2020) have called for more research on organizational listening and 
trust. In their examination of trust in the context of organizational communication and public relations, HungBaesecke and Chen (2020) found at least three ways in which to understand the concept of trust in the current research literature: 1 ) Sociologists perceive trust as a way to reduce or minimize negativity, enhance social relations, and connect the different sectors of a society; 2) the marketing and communication literature presents trust as confidence in making decisions about partners and the associated vulnerability; and 3) studies on interpersonal communication emphasize sincerity, benevolence, and honesty in developing trust in the interaction between individuals or groups of people.

On the societal level, trust is a lubricant for social relations, and it helps to build a prosperous society (Yamagishi, 2005), as it increases the society's ability to compete (Fukuyama, 1995) and engage in cooperation (Putnam, 2002, 2015). On the organizational level, trust advances relationship-building and diminishes risks (Hung-Baesecke \& Chen, 2020). Trust in public organizations ensures their legitimacy and furthers both public (Canel \& Luoma-aho, 2019) and political (Huang, Ao, Lu, Ip, \& Kao, 2017) participation. Trust motivates and empowers people (Harisalo \& Stenvall, 2003) and is also an important factor in people's decisionmaking about which information to consume (Moorman, Zaltman, \& Deshpande, 1992), making it essential during times of crisis.

Trust has been described as "a web" (Kim \& Ahmad, 2013), and it has also been claimed that trusting relationships help build further trusting relationships (Canel \& Luoma-aho, 2019; Smith \& Taylor, 2017). In fact, trust has been found to be contagious, especially in the online environment, and that, for example, trust in other people can transfer to trust in brands (Bowden, Conduit, Hollebeek, Luoma-aho, \& Solem, 2017; Reinikainen, Munnukka, Maity, \& Luoma-aho, 2020). Communication is an important factor in trust, as trust is formed through ongoing interaction (Canel \& Luoma-aho, 2019). It is also commonly understood as an important outcome of dialogue (Hung-Baesecke \& Chen, 2020; Yang, Kang, \& Cha, 2015).

Building on the previous literature on trust and organizational listening, the following hypotheses are suggested:

H3: Perceived organizational listening is positively associated with young people's trust in information that brands share on social media.

H4: Perceived organizational listening is positively associated with young people's trust in information that public authorities share on social media.

H5: Perceived organizational listening is positively associated with young people's trust in information that NGOs share on social media.

\section{Method and Data}

The study data were obtained through an online survey conducted in Finland and the UK to study social media and its effects on young people aged 15-30. The data were gathered in the spring of 2019 through a survey company utilizing an online panel. The data were anonymous, and the gathering was conducted in compliance with the requirements of the European General Data Protection Regulation, which regulates data protection and privacy in the European Union and the European Economic Area.

The online survey resulted in a total of 2,674 responses. As this study was specifically focused on the perceptions of the Generation Z cohort, respondents representing this generation were selected from the data for further analysis. Limiting the range of respondents to people aged 15-24 reduced the data to 1,534 responses. All the corresponding respondents reported using social media.

A quantitative approach was used to test the hypotheses. The online survey included several sections regarding different elements of social media. The more carefully studied variables included eight questions regarding the ways in which brands show interest in people on social media, two questions regarding perceptions about who benefits from brands' social media presence, and one question each regarding trust in the information provided by brands, public authorities, and NGOs (such as Red Cross or Greenpeace) on social media. All the variables were assessed on a five-point Likert scale ( $1=$ totally disagree, $5=$ totally agree). The eight questions about the interest that brands show in people on social media were operationalized as perceived organizational listening, as they captured elements related to answering questions, paying attention to people's opinions, seeking feedback, taking an interest in usercreated content, and replying to comments, which have been defined by Maben and Gearhart (2018) as organizational behaviors perceived as demonstrations of competent organizational listening. A summary variable, "perceived organizational listening," was formulated from these eight variables. Cronbach's alpha was calculated to test for internal consistency. The result $(\alpha=0.924)$ indicated good internal consistency.

The IBM SPSS Statistics software, version 24, was used for the statistical analyses. The analyses were based on the ordinary least squares (OLS) models, and to test hypotheses $\mathrm{H} 1-\mathrm{H} 5$, the following five variables were used as an outcome variable: 1) Perceived benefits for young people, generated by brand presence on social media (Model 1, Table 3); 2) perceived benefits for brands, generated by brand presence on social media (Model 2, Table 3); 3) trust in brands (Model 3, Table 4); 4) trust in public authorities (Model 4, Table 4); and 5) trust in NGOs (Model 5, Table 4). Perceived organizational listening was used as the explanatory variable in all five models, all of which were adjusted by gender, age, 
daily use of social media, place of residence, country, and education level.

In a post hoc analysis, we tested whether trust in brands, public authorities, and NGOs differed with respect to the level of organizational listening (low, moderate, high; Table 5). This was done by dividing the variable of perceived organizational listening into tertiles (low, moderate, and high), with each group containing a third of the study sample. Thereafter, we tested whether the level of organizational listening (low, moderate, high) was related to trust in brands (Table 6, Model 1), public authorities (Table 6, Model 2), and NGOs (Table 6, Model 3).

\section{Results}

\subsection{Descriptive Evidence}

The respondents' background information is presented in Table 1. All respondents aged 15-17 were Finnish, as the data from the UK did not include participants under the age of 18. In Finland 15-17-year-olds are allowed to participate in online surveys without parental consent.

All the respondents were avid users of social media; $70 \%$ of them completely agreed with the statement that social media were part of their everyday activity, while only $5 \%$ completely disagreed with the statement.
The respondents seemed fairly skeptical about how brands use social media to connect with them (see Table 2). For instance, the mean values of the statements "brands on social media benefit me" and "brands on social media benefit brands" were 3.55 (SD 1.23) and 4.32 (SD 0.98), respectively. This suggests that the respondents saw brand presence on social media as mostly beneficial to the respective brands, perceiving themselves as benefiting to a lesser extent. "They are only thinking about themselves and their reputation," one of the respondents commented through an open-ended field, referring to brand presence on social media.

The respondents also perceived brands as being only moderately interested in their opinions, experiences, recommendations, questions, and comments and as taking very little interest in the content that they have created and shared. As one of the respondents explained, "Brands are interested in the opinions of influencers and people with high profiles more than your average person."

In terms of trust, the respondents seemed to trust information shared by public authorities (mean value 3.66, SD 1.07) and NGOs (mean value 3.47, SD 1.08) more than they trusted information shared by brands (mean value 3.16, SD 1.13).

Table 1. Respondent profiles $(\mathrm{N}=1,534)$.

\begin{tabular}{|c|c|c|}
\hline Variable & $\%$ & $\mathrm{~N}$ \\
\hline \multicolumn{3}{|l|}{ Age } \\
\hline $15-17$ & 12 & 191 \\
\hline $18-20$ & 44 & 676 \\
\hline $21-24$ & 44 & 667 \\
\hline \multicolumn{3}{|c|}{ Social media are part of my everyday activity $(\mathrm{N}=1510)$} \\
\hline Completely disagree & 5 & 66 \\
\hline Partly disagree & 3 & 49 \\
\hline Neutral & 7 & 104 \\
\hline Partly agree & 15 & 232 \\
\hline Completely agree & 70 & 1059 \\
\hline \multicolumn{3}{|l|}{ Country } \\
\hline Finland & 49 & 752 \\
\hline UK & 51 & 782 \\
\hline \multicolumn{3}{|l|}{ Gender } \\
\hline Female & 51 & 777 \\
\hline Male & 48 & 743 \\
\hline Other & 1 & 14 \\
\hline \multicolumn{3}{|l|}{ Place of residence } \\
\hline Major city & 27 & 410 \\
\hline Big city & 29 & 442 \\
\hline Small city & 27 & 407 \\
\hline Rural are & 18 & 275 \\
\hline \multicolumn{3}{|l|}{ Education } \\
\hline Elementary school/Middle school & 13 & 192 \\
\hline High school/Vocational school & 45 & 685 \\
\hline College/University & 43 & 657 \\
\hline
\end{tabular}


Table 2. Descriptive statistics of perceived organizational listening and the outcome variables of interest.

\begin{tabular}{|c|c|c|}
\hline Variable & Mean & SD \\
\hline \multicolumn{3}{|l|}{ The benefits of brand presence on social media } \\
\hline Brands on social media benefit me & 3.55 & 1.23 \\
\hline Brands on social media benefit brands & 4.32 & 0.98 \\
\hline \multicolumn{3}{|l|}{ Perceived organizational listening ${ }^{1}$} \\
\hline I can influence brands by providing ideas for improvement and feedback & 3.15 & 1.33 \\
\hline Brands are interested in my opinions & 3.09 & 1.28 \\
\hline Brands are interested in my experiences & 3.42 & 1.21 \\
\hline Brands are interested in my recommendations & 3.10 & 1.29 \\
\hline Brands are interested in answering my questions & 3.31 & 1.23 \\
\hline Brands are interested in responding to my comments & 3.16 & 1.23 \\
\hline Brands are interested in photos I have shared & 2.85 & 1.37 \\
\hline Brands are interested in videos I have shared & 2.75 & 1.37 \\
\hline \multicolumn{3}{|l|}{ Trust in information shared on social media } \\
\hline I trust information from brands & 3.16 & 1.13 \\
\hline I trust information from public authorities & 3.66 & 1.07 \\
\hline I trust information from NGOs & 3.47 & 1.08 \\
\hline
\end{tabular}

Notes: ${ }^{1}$ Perceived organizational listening was formulated from the eight variables listed above. Cronbach's alpha was calculated to test the internal consistency of the variable, with the result $(\alpha=0.924)$ indicating good internal consistency.

\subsection{OLS Results}

The OLS results based on the respondents' perceptions of the benefits of social media are presented in Table 3, while Table 4 presents the results regarding trust in the information that brands, public authorities, and NGOs share on social media.

In terms of benefits, the results revealed that perceived organizational listening was positively related to the perceptions that brands on social media benefit young people (Table 3, Model 1 ) and that brands on social media benefit brands (Table 3, Model 2). On average, a one-unit increase in perceived organizational listening was related to a 0.07 -unit higher perception that brands on social media benefit young people and a 0.02-unit higher perception that brands on social media benefit brands. Thus, $\mathrm{H} 1$ and $\mathrm{H} 2$ were supported.

The results further revealed that perceived organizational listening was positively related to trust in the information that brands (Table 4, Model 3), public authorities

Table 3. Regression results for the perceived benefits.

\begin{tabular}{|c|c|c|}
\hline & $\begin{array}{c}\text { Model } 1 \\
\text { Benefits me }\end{array}$ & $\begin{array}{c}\text { Model } 2 \\
\text { Benefits brands }\end{array}$ \\
\hline \multirow[t]{2}{*}{ Perceived organizational listening } & $0.07 * * *$ & $0.02 * * *$ \\
\hline & $(0.004)$ & $(0.003)$ \\
\hline \multicolumn{3}{|l|}{ Control variables } \\
\hline \multirow[t]{2}{*}{ Age in years } & $-0.02 *$ & -0.10 \\
\hline & $(0.013)$ & $(0.011)$ \\
\hline \multirow[t]{2}{*}{ Gender (female) } & $-0.12 * *$ & $0.11^{* *}$ \\
\hline & $(0.059)$ & $(0.050)$ \\
\hline \multirow[t]{2}{*}{ Country (Finland) } & $0.15^{* *}$ & -0.09 \\
\hline & $(0.066)$ & $(0.056)$ \\
\hline \multirow[t]{2}{*}{ Use of social media } & $0.29 * * *$ & $0.34 * * *$ \\
\hline & $(0.029)$ & $(0.025)$ \\
\hline \multirow[t]{2}{*}{ Education } & 0.02 & 0.07 \\
\hline & $(0.051)$ & $(0.044)$ \\
\hline \multirow[t]{2}{*}{ Place of residence } & 0.01 & 0.01 \\
\hline & $(0.028)$ & $(0.024)$ \\
\hline Adjusted $\mathrm{R}^{2}$ & 0.29 & 0.18 \\
\hline $\mathrm{N}$ & 1277 & 1275 \\
\hline
\end{tabular}

Notes: Standard errors are in parentheses. Statistically significant at least at the $1 \%\left({ }^{* * *}\right), 5 \%\left({ }^{* *}\right)$, and $10 \%\left({ }^{*}\right)$ levels. 
Table 4. Regression results for trust in brands, public authorities, and NGOs.

\begin{tabular}{|c|c|c|c|}
\hline & $\begin{array}{l}\text { Model } 3 \\
\text { Trust in brands }\end{array}$ & $\begin{array}{c}\text { Model } 4 \\
\text { Trust in authorities }\end{array}$ & $\begin{array}{c}\text { Model } 5 \\
\text { Trust in NGOs }\end{array}$ \\
\hline Perceived organizational listening & $\begin{array}{l}0.07 * * * \\
(0.027)\end{array}$ & $\begin{array}{l}0.04 * * * \\
(0.003)\end{array}$ & $\begin{array}{l}0.04 * * * \\
(0.003)\end{array}$ \\
\hline \multicolumn{4}{|l|}{ Control variables } \\
\hline Age in years & $\begin{array}{l}-0.01 \\
(0.012)\end{array}$ & $\begin{array}{c}0.01 \\
(0.012)\end{array}$ & $\begin{array}{l}-0.02 \\
(0.013)\end{array}$ \\
\hline Gender (female) & $\begin{array}{l}-0.07 \\
(0.054)\end{array}$ & $\begin{array}{c}0.11^{*} \\
(0.057)\end{array}$ & $\begin{array}{c}0.05 \\
(0.057)\end{array}$ \\
\hline Country (Finland) & $\begin{array}{l}-0.27^{* * *} \\
(0.060)\end{array}$ & $\begin{array}{l}0.32 * * * \\
(0.063)\end{array}$ & $\begin{array}{l}-0.22^{* * *} \\
(0.064)\end{array}$ \\
\hline Use of social media & $\begin{array}{c}0.03 \\
(0.027)\end{array}$ & $\begin{array}{l}0.20 * * * \\
(0.028)\end{array}$ & $\begin{array}{l}0.13^{* * *} \\
(0.028)\end{array}$ \\
\hline Education & $\begin{array}{l}-0.06 \\
(0.047)\end{array}$ & $\begin{array}{c}0.02 \\
(0.050)\end{array}$ & $\begin{array}{l}0.05 \\
(0.050)\end{array}$ \\
\hline Place of residence & $\begin{array}{l}-0.02 \\
(0.026)\end{array}$ & $\begin{array}{c}0.01 \\
(0.027)\end{array}$ & $\begin{array}{l}-0.01 \\
(0.027)\end{array}$ \\
\hline Adjusted $\mathrm{R}^{2}$ & 0.28 & 0.14 & 0.14 \\
\hline $\mathrm{N}$ & 1270 & 1277 & 1268 \\
\hline
\end{tabular}

Notes: Standard errors are in parentheses. Statistically significant at least at the $1 \%\left({ }^{* * *}\right)$ and $10 \%\left({ }^{*}\right)$ levels.

(Table 4, Model 4), and NGOs (Table 4, Model 5) share on social media. On average, a one-unit increase in perceived organizational listening was related to a 0.07 -unit higher trust in brands, a 0.04-unit higher trust in public authorities, and a 0.04-unit higher trust in NGOs. Thus, $\mathrm{H} 3, \mathrm{H} 4$, and $\mathrm{H} 5$ were also supported.

Interestingly, adding country as a control variable showed significant differences in the respondents' trust in brands, public authorities, and NGOs. This is likely explained by the fact that Finnish people have traditionally reported higher levels of institutional trust than people from other European countries ("Survey: Finland ranks," 2018). The difference also seems to apply to this age cohort.

\subsection{Post Hoc Analysis}

Tables 5 and 6 report the results of the post hoc analysis. It appears that trust in brands, public authorities, and NGOs varied significantly with the level of perceived organizational listening (Table 5). For instance, respondents experiencing a low level of perceived organiza- tional listening also reported lower trust in brands, public authorities, and NGOs, while those experiencing a high level of perceived organizational listening reported higher levels of trust $(p<0.01)$.

Table 6 presents estimates regarding the relationship between the level of perceived organizational listening and trust in the information shared by brands, authorities, and NGOs on social media. For instance, those with a low level of perceived organizational listening had an approximately 1.22-unit lower trust in brands, a 0.57-unit lower trust in public authorities, and a 0.66-unit lower trust in NGOs compared with those with a high level of perceived organizational listening.

Based on the results of the post hoc analysis, a group of young people appeared to perceive that brands were listening to them on social media and that they had a higher feeling of trust in the information that brands, public authorities, and NGOs shared on social media. However, at the other end of the spectrum, there was a group of young people who felt that brands were not listening to them on social media. This latter group also seemed to have difficulty trusting the information that

Table 5. Summary statistics: Trust in information shared by brands, public authorities, and NGOs on social media, with perceived organizational listening tertiles (low, moderate, and high).

\begin{tabular}{lccr}
\hline Perceived organizational listening & Trust in brands & Trust in authorities & Trust in NGOs \\
\hline Low & 2.55 & 3.37 & 3.17 \\
Moderate & 3.10 & 3.64 & 3.40 \\
High & 3.81 & 3.97 & 3.88 \\
F-test & 167.05 & 33.91 & 50.19 \\
P-value & $\mathrm{p}<0.01$ & $\mathrm{p}<0.01$ & $\mathrm{p}<0.01$ \\
\hline
\end{tabular}

Notes: Perceived organizational listening divided into tertiles: Low, moderate, and high. Each group contains a third of the study sample. 
Table 6. Regression results for trust in brands, public authorities, and NGOs. Reference category: Perceived organizational listening, high.

\begin{tabular}{lccc}
\hline & Model 1 & Model 2 & Model 3 \\
& Trust in brands & Trust in authorities & Trust in NGOs \\
\hline Perceived organizational listening, low & $-1.22 * * *$ & $-0.57 * * *$ & $-0.66^{* * *}$ \\
& $(0.070)$ & $(0.072)$ & $(0.072)$ \\
Perceived organizational listening, moderate & $-0.63 * * *$ & $-0.33^{* * *}$ & $-0.40^{* * *}$ \\
& $(0.069)$ & $(0.071)$ & $(0.072)$ \\
Adjusted $\mathrm{R}^{2}$ & 0.22 & 0.11 & 0.11 \\
$\mathrm{~N}$ & 1270 & 1277 & 1268
\end{tabular}

Notes: Standard errors are in parentheses. Statistically significant at least at the $1 \%\left({ }^{* * *}\right)$ level. Perceived organizational listening divided into tertiles: Low, moderate, and high. Each group contains a third of the study sample. Reference category: Perceived organizational listening, high. The models were adjusted by gender, age, daily use of social media, place of residence, country, and education level.

brands and other organizations shared on social media. This suggests polarization in terms of perceived organizational listening and trust.

\section{Conclusion}

\subsection{Discussion}

This study has answered calls for more research on organizational listening and trust (Hung-Baesecke \& Chen, 2020; Macnamara, 2018b). It contributes to the understanding on organizational listening and trust in information shared on social media, the possible benefits of organizational listening, and perceptions regarding the organizational listening of young people within the age cohort of Generation Z.

The descriptive results showed that the respondents were skeptical about the level of attention they received from brands on social media. This supports the current knowledge that maintains that organizations are often unable to show signs of competent listening on social media (Maben \& Gearhart, 2018) and struggle with dialogue, especially when it comes to younger generations (Avidar et al., 2013). It therefore seems that the "architecture of listening" suggested by Macnamara (2016, 2018a, $2018 b)$ remains wanting.

Organizational listening on social media was found to be associated with the perception that brands' social media presence benefits both the brands and young people, although brands are currently perceived as benefitting substantially more. The results support earlier studies emphasizing that listening ensures that the interests of both organizations and stakeholders are met (Burnside-Lawry, 2012).

Further, the results showed that organizational listening was positively associated with trust in information shared on social media. Interestingly, it also seems that not only was organizational listening by brands on social media connected to trust in brands, but the perception of organizational listening by brands was also correlated with trust in the information shared by other organizations, such as public authorities and NGOs. This in- dicates that as young people perceive that their voices are being heard online, including by commercial organizations, they might be more inclined to trust different kinds of organizations and the content that these organizations share. It has been claimed that trust is contagious (Bowden et al., 2017), highlighting the responsibility that brands have on social media when it comes to listening to young people. Maintaining dialogue is a central value of democratic societies, and listening to young people online can be understood as an important contribution to societal benefits, such as increased trust (Macnamara, 2018b; Smith \& Taylor, 2017). Individual experiences matter collectively, as they may turn into more generalized experiences of trust (Rothstein \& Uslaner, 2005).

The results also showed a group of young people who seemed to perceive less organizational listening and experience less trust in the information that brands and other organizations share on social media. An earlier study on Millennials showed the different stances that young people take toward organizations in social media: While some actively build interaction with brands and organizations, others withdraw or completely avoid such interaction (Rissanen \& Luoma-aho, 2016). The same seems to apply to Generation Z.

Canel and Luoma-aho (2019) have maintained that, in the context of public organizations, citizens' positive experiences build further positive experiences and that high levels of citizen trust serve as a breeding ground for more trust, creating a kind of "virtuous circle of trust." At the same time, a "vicious circle of distrust" (Canel \& Luoma-aho, 2019) could be operating in the opposite direction: Negative experiences and distrust can also intensify. This raises the question of whether positive experiences of organizational listening and higher levels of trust can continue to reinforce each other and, thus, also support participation and engagement. In the same vein, negative perceptions of organizational listening and feelings of distrust can also accumulate, possibly contributing to heightened polarization, division, and even withdrawal from interaction on social media.

These developments could also manifest in the aftermath of the Covid-19 pandemic. Many in the Genera- 
tion $\mathrm{Z}$ cohort have demanded more forceful action against climate change, but they have seen very little response. They are now witnessing how quickly governments and the corporate world can act when faced with serious threats, such as a pandemic. As a result, many young people appear disappointed that a similar willingness to act has not been matched in the area of climate change (Margolin, 2020). These developments could affect their future trust in governments and the corporate world.

As mentioned earlier, Olkkonen and Jääskeläinen (2019) have framed corporate activism as "mobilizing talk," i.e., a phenomenon that brands often engage with in order to build relationships with consumers and stakeholders. If indeed positive experiences of organizational listening, trust, and participation are intertwined, there might also be room for an approach called "mobilizing listening." This would suggest that brands and organizations showing signs of active and competent listening could potentially accelerate young people's trust and, therefore, contribute to their participation and engagement online.

Noteworthy, however, is that this scenario represents an ideal state in the sense that the drivers of brands are seldom individual or societal needs; instead, they are financial gains. While Nike took a risk in its collaboration with Colin Kaepernick to take a stand on an important societal issue and faced criticism and even boycotts because of it, Nike's sales were eventually boosted, and their stock rose by $5 \%$ in the weeks following the launch of the campaign ("Nike's 'dream crazy' advert," 2019). The risk was, therefore, well calculated.

True dialogue includes reciprocity and responsiveness (Ciszek \& Logan, 2018; Smith \& Taylor, 2017), and it seems that when it comes to Generation Z, brands and organizations still have a long way to go. There is an upward trend in young people's expectations toward brands and other organizations, juxtaposed with a downward trend in trust. Young people want their voices heard, and brands and organizations can play a role in facilitating this societal need. By improving their competence in listening on social media, brands and organizations might not only themselves benefit, including in terms of increased trust in them, but they might also increase the perceived benefits of social media for young people and, therefore, possibly even empower them.

\subsection{Limitations and Future Studies}

Although this study has several limitations, it also opens up interesting avenues for further research. First, the results only showed correlations, as opposed to causal effects, between the variables. The effects of organizational listening would be better observed, for example, through an experimental design, where manipulated conditions for listening (high level of listening versus low level of listening) are presented to the respondents.

Also, the data were secondary in nature, i.e., not originally gathered to study organizational listening.
Therefore, it is possible that the variables used to capture organizational listening did not cover all aspects of what is considered to be good and competent organizational listening on social media. For instance, the dimension of "pertinent response" (Maben \& Gearhart, 2018) was lacking from the variables used. A more carefully designed measure for organizational listening should be used in future studies to verify the results. Also, as all the variables were obtained through a self-reported online survey, some measurement errors may exist.

In addition, the questionnaire did not include different types of perceived benefits. Within the context of brands on social media, these could include financial benefits in terms of promotional codes, emotional benefits in terms of contact and interaction with brand representatives or other social media users, or recreational benefits in terms of entertaining or amusing content. Future studies could look at the connections between perceived organizational listening and the different types of perceived benefits.

The study respondents fell exclusively between the ages of 15 and 24, which means that the youngest representatives of Generation $Z$ were missing from the data. Therefore, the results might not be applicable to the entire age cohort of Generation Z. Further studies should seek to include those who are currently 10-14 years old.

The fact that the respondents came from Finland and the UK, both western democracies with relatively high Internet access and social media use, also challenges the representativeness of the study. The results might, therefore, not be applicable to the entire global Generation Z population. A comparison with more countries could offer insights into whether those in Generation Z have more cross-country similarities or differences when it comes to experiencing organizational listening and trust on social media.

The differences in age and culture between the respondents might also have affected the results. The Finnish respondents were aged 15-24, while the UK respondents were 18-24. Although the respondents' age, country, and place of residence were taken into account, a wide range of unobserved factors might have remained. For example, Finnish people have traditionally reported higher levels of trust in public institutions ("Survey: Finland ranks," 2018) than people from other European countries, which might also have affected the results. Future studies could look deeper, for example, at whether different levels of polarization and transparency in different societies affect the perceptions of trust in information shared by brands and organizations on social media.

Finally, as this study is a snapshot, it is difficult to say whether the perceptions of the respondents regarding organizational listening and trust were connected with their life stage or generation. This is something that only longitudinal research can tell. In addition, the entire concept of Generation $Z$ can be questioned. Urwin and Parry (2017), for example, have suggested that generations 
may actually be distinct points on a more general social journey as people become more accepting of different ideas.

\section{Acknowledgments}

This study has been supported by the Academy of Finland (decision number 320373).

\section{Conflict of Interests}

The authors declare no conflicts of interest.

\section{References}

Alter, C. (2018, March 22). The school shooting generation has had enough. Time. Retrieved from https:// time.com/longform/never-again-movement

Alter, C., Haynes, S., \& Worland, J. (2019, December 11). Time 2019 person of the year-Greta Thunberg. Time. Retrieved from https://time.com/person-ofthe-year-2019-greta-thunberg

Avidar, R., Ariel, Y., Malka, V., \& Levy, E. C. (2013). Smartphones and young publics: A new challenge for public relations practice and relationship building. Public Relations Review, 39(5), 603-605.

Barbiroglio, E. (2019, December 9). Generation Z fears climate change more than anything else. Forbes. Retrieved from https://www.forbes.com/sites/ emanuelabarbiroglio/2019/12/09/generation-zfears-climate-change-more-than-anything-else/ \#488149dd501b

Bowden, J., Conduit, J., Hollebeek, L., Luoma-aho, V., \& Solem, B. (2017). Engagement valence duality and spillover effects in online brand communities. Journal of Service Theory and Practice, 27(4), 877-897.

Burnside-Lawry, J. (2012). Listening and participatory communication: A model to assess organization listening competency. International Journal of Listening, 26(2), 102-121.

Canel, M., \& Luoma-aho, V. (2019). Public sector communication: Closing gaps between public sector organizations and citizens. Boston, MA: Wiley.

Cheng, Y., Jin, Y., Hung-Baesecke, C.-J. F., \& Chen, Y.R. R. (2019). Mobile corporate social responsibility (mCSR): Examining publics' responses to CSR-based initiatives in natural disasters. International Journal of Strategic Communication, 13(1), 76-93.

Ciszek, E., \& Logan, N. (2018). Challenging the dialogic promise: How Ben \& Jerry's support for Black Lives Matter fosters dissensus on social media. Journal of Public Relations Research, 30(3), 115-127.

Crawford, K. (2009). Following you: Disciplines of listening in social media. Continuum: Journal of Media \& Cultural Studies, 23(4), 525-535.

Deloitte. (2019). Deloitte research reveals a "generation disrupted": Growing up in a world of accelerated transformation leaves Millennials and Gen Zs feeling unsettled about the future. Deloitte. Retrieved from https://www2.deloitte.com/global/en/pages/ about-deloitte/press-releases/deloitte-millennialsurvey-research-reveals-gen-z-unsettled.html\#

Dodd, M. D., \& Collins, S. J. (2017). Public relations message strategies and public diplomacy 2.0: An empirical analysis using Central-Eastern European and Western Embassy Twitter accounts. Public Relations Review, 43(2), 417-425.

Dodd, M. D., \& Supa, D. W. (2014). Conceptualizing and measuring "corporate social advocacy" communication: Examining the impact on corporate financial performance. Public Relations Journal, 8(3). Retrieved from http://www.prsa.org/Intelligence/ PRJournal/Vol8/No3

Edelman. (2018). Edelman trust barometer 2018: Global results. Edelman. Retrieved from https:// www.edelman.com/research/2018-edelman-trustbarometer

Edelman. (2020). Edelman trust barometer 2020: Global results. Edelman. Retrieved from https:// www.edelman.com/trustbarometer

Francis, T., \& Hoefel, F. (2018). 'True gen': Generation Z and its implications for companies. Retrieved from https://www.mckinsey.com/industries/consumerpackaged-goods/our-insights/true-gen-generationz-and-its-implications-for-companies\#

Fukuyama, F. (1995). Trust: The social virtues and the creation of prosperity. New York, NY: Free Press.

Harisalo, R., \& Stenvall, J. (2003). Trust management in Finnish ministries: Evaluation of management systems. International Journal of Public Administration, 26(8/9), 915-940.

Herrando, C., Jimenez-Martinez, M., \& Martin-De Hoyos, M. J. (2019). Tell me your age and I tell you what you trust: the moderating effect of generations. Internet Research, 29(4), 799-817.

Huang, Y.-I. C., Ao, S., Lu, Y., Ip, C., \& Kao, L. (2017). How trust and dialogue shape political participation in mainland China. International Journal of Strategic Communication, 11(5), 395-414.

Hung-Baesecke, C.-J. F., \& Chen, Y.-R. R. (2020). Explicating trust and its relation to dialogue at a time of divided societies. Public Relations Review, 46(1), 101890. https://doi.org/10.1016/j.pubrev.2020. 101890

Ji, Y. G., Li, C., North, M., \& Liu, J. (2017). Staking reputation on stakeholders: How does stakeholders' Facebook engagement help or ruin a company's reputation? Public Relations Review, 43(1), 201-210.

Kent, M. L., \& Taylor, M. (1998). Building dialogic relationships through the world wide web. Public Relations Review, 24(3), 321-334.

Khan, N., Wang, J., \& Yoon, F. (2019, November 15). The 11-year-old dissident: Hong Kong's schoolchildren fuel protests. The Wall Street Journal. Retrieved from https://www.wsj.com/articles/schoolchildrenpropel-hong-kong-protests-11573833842 
Kim, Y. A., \& Ahmad, M. A. (2013). Trust, distrust and lack of confidence of users in online social media sharing communities. Knowledge-Based Systems, 37, 438-450.

Kim, Y., Russo, S., \& Amnå, E. (2017). The longitudinal relation between online and offline political participation among youth at two different developmental stages. New Media \& Society, 19(6), 899-917.

Lane, A. B. (2018). If it's so good, why not make them do it? Why true dialogue cannot be mandated. Public Relations Review, 44(5), 656-666.

Len-Ríos, M. E., Hughes, H. E., McKee, L. G., \& Young, H. N. (2016). Early adolescents as publics: A national survey of teens with social media accounts, their media user preferences, parental mediation, and perceived Internet literacy. Public Relations Review, 42(1), 101-108.

Lovari, A., \& Parisi, L. (2015). Listening to digital publics. Investigating citizens' voices and engagement within Italian municipalities' Facebook pages. Public Relations Review, 41(2), 205-213.

Maben, S. K., \& Gearhart, C. C. (2018). Organizational social media accounts: Moving toward listening competency. International Journal of Listening, 32(2), 101-114.

Macnamara, J. (2016). Organizational listening: Addressing a major gap in public relations theory and practice. Journal of Public Relations Research, 28(3/4), 146-169.

Macnamara, J. (2018a). The missing half of communication and engagement: Listening. In K. A. Johnston \& M. Taylor (Eds.), The handbook of communication engagement (pp. 115-132). Hoboken, NJ: WileyBlackwell.

Macnamara, J. (2018b). Toward a theory and practice of organizational listening. International Journal of Listening, 32(1), 1-23.

Macnamara, J. (2019). Explicating listening in organization-public communication: Theory, practices, technologies. International Journal of Communication, 13, 5183-5204.

Margolin, J. (2020, March 26). Politicians blew off Gen Z's climate goals: The coronavirus shows we can act fast. The Washington Post. Retrieved from https://bit.ly/ 2K9aLNY

Meriac, J. P., Woehr, D. J., \& Banister, C. (2010). Generational differences in work ethic: An examination of measurement equivalence across three cohorts. Journal of Business and Psychology, 25(2), 315-324.

Minár, P. (2016). Goodvertising as a paradigmatic change in contemporary advertising and corporate strategy. Communication Today, 7(2), 4-17.

Moorman, C., Zaltman, G., \& Deshpande, R. (1992). Relationships between providers and users of market research: The dynamics of trust within and between organizations. Journal of Marketing Research, 29(3), 314-328.

Mukherjee, R., \& Banet-Weiser, S. (2012). Commodity ac- tivism: Cultural resistance in neoliberal times. New York, NY: New York University Press.

Nike's 'dream crazy' advert starring Colin Kaepernick wins Emmy. (2019, September 16). The Guardian. Retrieved from https://www.theguardian.com/sport/ 2019/sep/16/nikes-dream-crazy-advert-starringcolin-kaepernick-wins-emmy

Olkkonen, L., \& Jääskeläinen, J. (2019). “Mobilizing talk" as CSR communication? Three examples of corporate activism. In M. Morsing, U. Golob, \& K. Podnar (Eds.), CSR Communication Conference 2019: Conference proceedings (pp. 107-113). Retrieved from http://csr-com.org/img/upload/final_ CSRCOMproceedings2019_web.pdf

Ostrander, M. (2019, August 23). In 2020, millennials and generation $Z$ could force politicians to deal with climate change. The Nation. Retrieved from https://www.thenation.com/article/archive/climatechange-youth-public-opinion-election-2020

Pina, L. S., Loureiro, S. M. C., Rita, P., Sarmento, E. M., Bilro, R. G., \& Guerreiro, J. (2019). Analysing consumer-brand engagement through appreciative listening on social network platforms. Journal of Promotion Management, 25(3), 304-313.

Priporas, C.-V., Stylos, N., \& Fotiadis, A. K. (2017). Generation $Z$ consumers' expectations of interactions in smart retailing: A future agenda. Computers in $\mathrm{Hu}$ man Behavior, 77, 374-381.

Putnam, R. D. (Ed.). (2002). Democracies in flux: The evolution of social capital in contemporary society. New York, NY: Oxford University Press.

Putnam, R. D. (2015). Our kids: The American dream in crisis. New York, NY: Simon and Schuster.

Reinikainen, H., Munnukka, J., Maity, D., \& Luoma-aho, V. (2020). 'You really are a great big sister'-Parasocial relationships, credibility, and the moderating role of audience comments in influencer marketing. Journal of Marketing Management, 36(3/4), 279-298.

Rissanen, H., \& Luoma-aho, V. (2016). (Un)willing to engage? First look at the engagement types of millennials. Corporate Communications: An International Journal, 21(4), 500-515.

Rothstein, B., \& Stolle, D. (2008) The state and social capital: An institutional theory of generalized trust. Comparative Politics, 40(4), 441-459.

Rothstein, B., \& Uslaner, E. (2005). All for all: Equality, corruption, and social trust. World Politics, 58(1), 41-72.

Russmann, U., \& Lane, A. B. (2020). Mandating dialogue? International perspectives on differences between theory and practice. Public Relations Review, 46(1), 101819.

Smith, B., \& Taylor, M. (2017). Empowering engagement: Understanding social media user sense of influence. International Journal of Strategic Communication, 11(2), 148-164.

Sommerfeldt, E. J., \& Kent, M. L. (2015). Civil society, networks, and relationship management: Beyond the organization-public dyad. International Journal of 
Strategic Communication, 9(3), 235-252.

Sommerfeldt, E. J., \& Yang, A. (2018). Notes on a dialogue: Twenty years of digital dialogic communication research in public relations. Journal of Public Relations Research, 30(3), 59-64.

Southgate, D. (2017). The emergence of Generation Z and its impact in advertising: Long-term implications for media planning and creative development. Journal of Advertising Research, 57(2), 227-235.

Survey: Finland ranks number one in citizen trust. (2018, June 24). YLE. Retrieved from https://yle.fi/ uutiset/osasto/news/survey_finland_ranks_ number_one_in_citizen_trust/10270981

Taylor, M. (2011). Building social capital through rhetoric and public relations. Management Communication Quarterly, 25(3), 436-454.

Taylor, M., \& Kent, M. L. (2014). Dialogic engagement: Clarifying foundational concepts. Journal of Public Relations Research, 26(5), 384-398.

Tirkkonen, P., \& Luoma-aho, V. (2011). Online authority communication during an epidemic: A Finnish example. Public Relations Review, 37(2), 172-174.

Topping, A., Lyons, K., \& Weaver, M. (2019, January 15). Gillette \#MeToo razors ad on 'toxic masculinity' gets praise-and abuse. The Guardian. Retrieved from https://www.theguardian.com/world/2019/jan/15/ gillette-metoo-ad-on-toxic-masculinity-cuts-deepwith-mens-rights-activists

Turner, A. (2015). Generation Z: Technology and social interest. The Journal of Individual Psychology, 71(2), 103-113.

Urwin, P. J., \& Parry, E. (2017). The evidence-base for generational differences: Where do we go from here? Work, Aging and Retirement, 3(2), 140-148.

Vos, M. (2016). Reputation monitoring. In C. E. Carroll (Ed.), The Sage encyclopedia of corporate reputation (pp. 657-659). Thousand Oaks, CA: Sage.

Willis, P. (2015). Preach wine and serve vinegar: Public relations, relationships and doublethink. Public Relations Review, 41(5), 681-688.

Yamagishi, T. (2005). Trust. In G. Ritzer (Ed.), Encyclopedia of social theory (pp. 847-848). Thousand Oaks, CA: Sage.

Yang, S.-U., Kang, M., \& Cha, H. (2015). A study on dialogic communication, trust, and distrust: Testing a scale for measuring organization-public dialogic communication (OPDC). Journal of Public Relations Research, 27(2), 175-192.

\section{About the Authors}

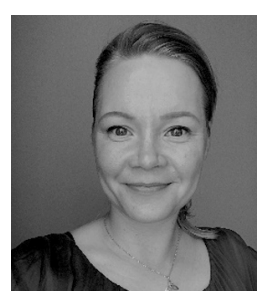

Hanna Reinikainen is a Doctoral Student in Corporate Communication at the Jyväskylä University School of Business and Economics. Her PhD focuses on social media influencers and interaction on social media. She currently works on a research project on young people's agency on social media, funded by the Academy of Finland. https://orcid.org/0000-0002-3165-4889

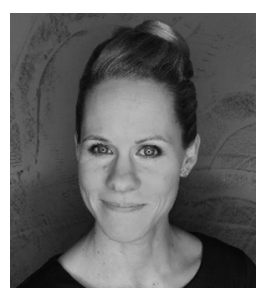

Jaana T. Kari is a Postdoctoral Researcher in Economics at the Jyväskylä University School of Business and Economics. Her PhD focused on lifelong physical activity and long-term labor market outcomes. Currently, her research focuses on young people's health and wellbeing and their impact on the accumulation of lifetime human capital. https://orcid.org/0000-0001-5205-7031

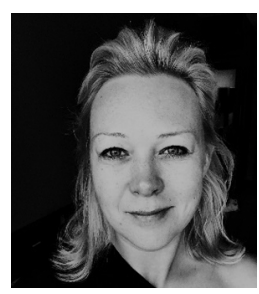

Vilma Luoma-aho is a Professor of Corporate Communication and the Vice Dean of Research at the Jyväskylä University School of Business and Economics. Her research focuses on intangible assets, and she currently leads an Academy of Finland-funded research project on young people and social media. Her latest edited book, The Handbook of Public Sector Communication (Wiley), is out in 2020. https://orcid.org/0000-0003-1316-3725 